\title{
THE RIGHT TO MEMBERSHIP IN A LABOR UNION
}

By Homer H. Hewitt 3RD $\dagger$

The remarkable advance of organized labor, from about three million to more than sixteen million members, has been one of the most significant developments of the past two decades. As an integral part of the industrial economy, what unions do, what they think, how well they function as representatives of the workers, affects the life of the entire nation.

Unions have fought for and now stand for fundamental principles of industrial democracy; yet, in the basic field of membership, labor's record is sullied by the undemocratic practices of some unions. While only a relatively small segment of organized labor is involved, most unions being open to all qualified applicants, the restrictive admission policies of even a few unions can affect the lives of thousands of workers and supply enemies of labor with weapons to use against the entire trade union movement. Not merely an internal matter, the acute problems caused by such policies, and the role the law can play in alleviating these problems, merit consideration and appraisal.

\section{The Admission Policies of Unions}

The first of the two major types of restrictions is that practiced by "closed unions". These unions limit the number of full-fledged members, usually to protect their members from employment fluctuation, depression, or technological change, but occasionally to exploit a monopolistic control over the labor supply. Unions are generally closed by charging high initiation fees, by using a permit system, or, most commonly, by simply closing the books to new applicants. Two factors limit the spread of closed unions: the natural desire of the national unions to have a large membership, and the necessity of having almost complete control of the job market, preferably including control of hiring as well as a closed or union shop. As the closed union type of restriction is directed toward control over employment, the main problem involved is the right to work and not the right to membership. Whether the closed union and closed shop are unqualifiedly incompatible, or whether a union should in some circumstances be able to

$\dagger$ A. A., Princeton University, 1947; LL. B., Harvard University, 1949; Member of the Philadelphia Bar.

1. See American Civil Liberties Union, Democracy in Trade Unions 12-15 (1943). 
control the labor supply by its membership policy, is not a problem here. If the current trend of the cases continues some measure of legal relief will be available to prevent abuses in this field. ${ }^{2}$

The second major type of restriction is discrimination against applicants because of personal characteristics such as race, religion, citizenship, political beliefs or national origin. Reasons given for such restrictions are the desire to protect the members against the "cheap labor" of Negroes, Orientals, aliens or other groups; the fear of disruption within the union resulting from admission of Communists, women, or Negroes; and the social attitudes and prejudice, at least partly based on the same economic advantages perpetuated by exclusion, of the members themselves. Exclusion may take the form of an outright bar or may be accomplished by the use of competency tests, high initiation fees, state licensing, apprenticeship or an "auxiliary" system.

Since admission is generally administered by the locals, and thus may vary according to the views and prejudices of their members, the extent of discrimination is difficult to measure. But as the policy of the national union is usually followed, a determination of its admission policies, usually shown in constitution or by-laws, provides a general guide.

While the individual effect is of course severe, it is probable that exclusion because of religion, sex, and citizenship is not now widespread. Religious discrimination, rarely openly expressed, is probably negligible, ${ }^{3}$ and restrictions on women membership have decreased. ${ }^{4}$ Citizenship barriers are more frequently encountered and thus more serious, some twenty-nine unions having constitutional restrictions in $1946,{ }^{5}$ but are not common. It is doubtful that provisions excluding adherents of certain political beliefs have, at least until recently, been rigidly enforced. ${ }^{6}$

Although the injustice involved in the above instances demands correction, the most serious of the discriminatory restrictions, because of its extent and its harmful effect, is exclusion because of race. Again

2. See note 10 supra. (1946).

3. Summers, Admission Policics of Labor Unions, 61 Q. of EcoN. 66, 76-77

4. Women now represent one-fifth of organized labor, as opposed to less than ten per cent in 1937. 9 Labor Research Association, Labor Fact Book 118 (1949).

5. Including such strong unions as the Carpenters and the Teamsters, Summers, supra note 3 , at 73 .

6. American Civil Liberties Union, supra note 1, at 11. Many of these are insignificant restrictions, such as exclusion of members of the NAM, but increasing enforcement of anti-Communist provisions raises a problem involving a delicate balance of internal harmony against democratic admissions. Alternative measures such as a disclosure apparatus, alerting of members, or even denial of union office seem preferable to outright exclusion. 
it must be stressed that only a minority of organized labor excludes on racial grounds. But it is a substantial minority, consisting of unions which total almost two million members. Although the racial discrimination may encompass Indians, Mexicans, and Orientals, it is primarily directed against Negroes.

Methods of racial discrimination include constitutional bars, exclusion by custom or ritual, and relegation to Jim Crow auxiliaries, subordinate to the "lily white" locals. A 1946 study of admission policies indicated that thirty-two unions, almost one-fifth of organized labor, denied full membership to Negroes. ${ }^{7}$ More recent figures show at least twenty-three unions denying full membership rights. ${ }^{8}$ Among these are such powerful groups as the Locomotive Engineers, Railroad Trainmen, and the Plumbers and Steamfitters.

Exclusion because of race, like other restrictions, is seldom the policy of industrial unions. Since its inception, the CIO has encouraged the inclusion of Negroes and has followed a positive program of improving the Negro worker's status within unions and industry. CIO unions, therefore, raise no barrier to admission of Negroes, although there may be a certain amount of discrimination at the local level. The AFL has also had an avowed policy against discrimination but has not been as successful. A number of AFL affiliates, most of which are old-line, craft-conscious unions, still exclude Negroes. ${ }^{9}$

The arbitrary restrictions imposed by some unions, depriving workers of many advantages represent a compromise of the ideals and objectives of organized labor and, as such, increase labor's vulnerability to attack. Clearly the best method of remedying this defect would be from within, with the unions themselves ensuring democratic admission practices through education and a firm anti-discrimination policy. ${ }^{10}$ But, without judicial prodding, such a course can be painstakingly slow and might never reach fulfillment. Unjust treatment should not have to wait upon evolutionary processes. Some remedy should be immediately available to the excluded worker; perhaps the courts can provide it.

7. Summers, supra note 3 . See also, Northrup, Organized Labor aNd the NEGRO, (1942).

8. Murray, The Negro Handbook 162-3 (1949). Some large unions at least partially reformed their restrictive policies in recent years; Id. at 165-7. The Machinists, with over 600,000 members, have recently turned to industrial unionism, apparently discarding former discriminatory policies.

9. See Summers, supra note 3, at 68-72; Murray, supra note 8, at 162-163.

10. Noteworthy have been the efforts and achievements of the UAW-CIO in establishing an active, well-staffed Fair Practices and Anti-Discrimination Department and local Fair Practices Committees. This program of fighting union and industry discrimination has been highly successful, even in the South. REUTHER. Report of the President to the 12th Convention of the UAW-CiO (July 10, 1949). 
When a union which maintains a restrictive admission policy is the representative of the employees in a bargaining unit, the status of excluded members of that unit is insecure. They cannot participate in union activities and yet they are governed by union action. Whether such employees have a right to membership in the representative union thus becomes a vital question.

This problem is to be distinguished from two others, which may be considered as other facets of the general problem of union democracy: the right to work, ${ }^{11}$ and the right to fair representation. ${ }^{12}$ Generally, these two doctrines are designed to protect the worker against arbitrary dismissal and against unjust treatment as a result of acts of the union, but neither purport to confer membership rights upon the excluded worker.

The traditional answer of the courts to the membership question has been that there is no right to join a union. ${ }^{13}$ But such a position has been challenged as ill-suited to the industrial world of today, where, under the protection of federal and state legislation, labor unions have become an operative part of industry, making decisions that affect the daily lives of many thousands of workers. In view of the power and functions of the representative union, the position of the courts should be examined to determine whether their apparent refusal to recognize a right to membership is either desirable or necessary. In conjunction with the study of the attitude of the judiciary, the policies of the National Labor Relations Board and of the legislatures will be briefly considered.

11. On the subject of discharge at the demand of the union, the RESTATEMrENT, TORTS $\$ 810$ (1939) states:

"Workers who in concert procure the dismissal of an employee because he is not a member of a labor union satisfactory to the workers are .. liable to the employee if, but only if, he desires to be a member of the labor union but membership is not open to him on reasonable terms."

Dismissal because of arbitrary exclusion is also enjoinable. Despite apparent similarity, courts have not yet extended this principle to the right to obtain employment. See Wilson v. Newspaper and Mail Deliverers' Union, 123 N.J. Eq. 347, 197 Atl. 720 (ch. 1938); Williams v. International Brotherhood of Boilermakers, 27 Cal.2d 586, 165 P.2d 903 (1946) ; James v. Marinship Corporation, 25 Cal.2d 721,155 P.2d 329 (1944); Lucke v. Clothing and Trimmers' Assembly No. 7507, 77 Md. 396, 26 Atl. 505 (1893) ; Dorrington v. Manning, 135 Pa. Super. 194, 4 A.2d 886 (1938); Wills v. Local No. 106, Hotel and Restaurant Employees, 26 Ohio N.P. (N.S.) 435 (C.P. 1932) ; Schwab v. Moving Picture Machine Operators, 165 Ore. 602,109 P.2d 600 (1941).

12. In Steele v. Louisville \& N.R.R., 323 U.S. 192 (1944), the Supreme Court held that the chosen union assumes the duty to represent all employees "fairly, impartially, and in good faith." See Graham v. Brotherhood of Locomotive Firemen and Enginemen, 338 U.S. 232 (1949).

13. Mayer v. Journeymen Stone Cutters' Association, 47 N.J. Eq. 519, 20 Atl. 492 (Ch. 1890); Miller v. Ruehl, 166 N.Y. Misc. 479, 2 N.Y.S.2d 394 (Sup. Ct. 1938); Walter v. McCarvel, 309 Mass. 260, 34 N.E.2d 677 (1941) 


\section{Power and Functions of the Representative}

When a union has been selected and is securely settled as bargaining representative for the employees of a company or industry, those employees should, for their own benefit and protection, be both willing and able to join that union. While recognition of a right to work may enable an excluded worker to obtain or retain a job, and protection of the right to a fair representation will, to some extent, eliminate unjust discrimination against him, neither of these legal safeguards will give the worker a voice in formulating the terms and conditions under which he will work. Because of the intangibles involved and the difficulty of proving unfair differentiation, the right to a fair representation has not, in its enforcement, always proved effective in preventing unjust treatment. And if the worker is not a participant, he may not always know whether he is being fairly represented. The major practical reason, however, for giving each worker a reasonable opportunity to join the union which is his bargaining representative, is the power of that union over his economic and social life.

The primary source of the chosen union's power lies in its position as the sole representative of all the employees in the bargaining unit. In the National Labor Relations Act, Section 9(a) confers this power on the union:

"Representatives designated or selected for the purposes of collective bargaining by the majority of the employees in a unit appropriate for such purposes, shall be the exclusive representatives of all the employees in such unit. . . ."14

The cases illustrate the importance and extent of the position of exclusive representative. There is an affirmative duty on the part of the employer to deal with the majority representative and a negative duty to deal with no other. ${ }^{15}$ The union is to be bargaining agent for all the employees, not just members of the union. ${ }^{16}$ Once the union is chosen by the majority, the employer must deal exclusively with it as to all terms and conditions of employment, regardless of any individual contracts previously made. ${ }^{17}$ This is true even though the majority of the employees are trying to deal with the employer, at least as long as the union's authority as representative has not been revoked. ${ }^{18}$ The

14. 49 Stat. 453,29 U.S.C. $\$ 159 \mathrm{a}$ (1935).

15. North Electric Mfg. Co. v. NLRB, 123 F.2d 887 (6th Cir. 1941) ; Texarkana Bus Co. v. NLRB, 119 F.2d 480 (8th Cir. 1941).

16. McQuay-Norris Mfg. Co. v. NLRB, 116 F.2d 748 (7th Cir. 1940); Hartzell Mills Co. v. NLRB, 111 F.2d 291 (4th Cir. 1940).

17. J.I. Case Co v NLRB, 321 U.S. 332 (1944) ; Order of Railroad Telegraphers v. Railway Express Agency, 321 U.S. 342 (1944).

18. Medo Photo Supply Corp. v. NLRB, 321 U.S. 678 (1944). 
collective bargaining agreement is more important than individual contracts, even in such vital areas as seniority. ${ }^{19}$ The courts have thus affirmed the power of the union to control the determination of issues which affect every employee in the unit.

The area in which the union functions, as defined by the National Labor Relations Act, is that of "wages, hours, and other terms and conditions of employment". In accordance with the purposes of the act, this phrase encompasses a wide range of employment provisions. The representative union will decide, by means of a collective bargaining contract, how much the excluded worker will be paid, when he will work, when he may have a vacation, when he may be laid off or discharged, and what he will receive as pension when he retires.

A glance at the provisions of collective bargaining agreements reveals the extent of the control of the union over the employee's economic affairs. ${ }^{20}$ In the field of wages, the contract may cover time of payment, wage differentials, waiting time compensation, extra pay for hazardous work, or profit-sharing plans. Under hours are terms designating the starting and quitting time, clean-up time, meal and rest periods, and overtime. Shift scheduling and Sunday and holiday work may be covered. Vacation rights and periods and excusable absences will be outlined. A seniority system will be set up, defining the operation of the seniority principle on both layoffs and promotions. Provisions covering such items as technological change, apprenticeship rules, employee patent rights, safety rules and change in plant site may also be included.

In the field of grievances the power of the union is again felt. From the shop committee stage, up to arbitration, the union is generally in control. Committees are staffed by union men and often the latter stages are exclusively in the union's hands. Here, discrimination against non-members could be subconscious, or so subtle that no proof could be made to a court. Although it may or may not violate the duty to represent fairly, some collective bargaining contracts have contained provisions that the union can exclude non-members from the established grievance machinery, leaving the worker only with the right to take his grievance directly to the company.

Another important field, which has developed in recent years, is the field of social insurance. Unions now make agreements with employers covering health, life and accident insurance and pension plans. Extension of union activity into these fields of such personal

19. Llewellyn v. Fleming, 154 F2d 211 (10th Cir. 1946).

20. See Union Agreement Provisions, U. S. Dept. of Labor B. L. S. Bull. No. 686 ; C.C.H. Labor Law Reporter No 5. 
impact is another strong reason for employee participation in decision-making.

Thus, almost from cradle to grave, the pattern of the excluded worker's economic life, and through that to his social life, is set by the bargaining representative. Generally, of course, the union will try to further the interests of all workers. But in some cases-the railroad brotherhoods for example-the union leadership may manifest hostility to some particular minority group of workers. To bestow union membership upon that minority will not necessarily allay the friction between it and the dominant group. But it will at least provide a basis for an opportunity for the minority to be heard, and perhaps, further, a basis for a common understanding in the future. Certainly open membership is the minimum protection which an employee should have against abuses of power by the union.

The strength of the union is not, however, the only reason for recognizing a right to membership. Equally important is the peculiar position of unions in an industrial society. They do not exist solely to gain economic advantages for workers, nor are they exclusively an economic pressure group. The labor union is also a political organ, designed to instill democracy in the industrial society.

As one writer has pointed out, ${ }^{21}$ the industrial or business enterprise commands vital authority over men and is in that sense a governmental or ruling institution. But as its main function is the production of goods, it can never be a "legitimate" government, that is, ruling in the interests of the people, for the welfare of its members must always be a secondary concern. Management cannot be "for" the people, nor, realistically, "by" or "of" the people. To supply the need for representation of the people, labor unions arose. The unionization of industry and the installation of collective bargaining has had two beneficial effects: the psychological or spiritual impact, giving the member a sense of human dignity because he "belongs" and because he shares in guiding his own destiny; ${ }^{22}$ and the democratic impact, making economic government, as far as possible, an expression of the will of its citizens.

Section 9(a) of the NLRA embodies these principles when it provides, not for "collective bargaining directors", but for "representatives". The section enunciates a system of representative democracy in economic government whereby each worker plays a part in determining the nature of his economic and social existence. No measure

21. Drucker, “The New Society," Harper's November, 1949, p. 199. (1942).

22. See Golden and Ruttenberg, The Dynamics of Industrial Democracy, 
can be placed on the psychological value of participation in the decisional process, but there can be no doubt that the benefits derived from the resulting sense of individual worth and responsibility are great.

Unjustified exclusion of any member of the bargaining unit is a repudiation of the democratic, the representative, function of the union. Only through the union can the worker exercise his bargaining power and his right to be heard. If the worker has no share in deciding what his wages will be, when a strike is to be called, or how seniority will operate, no substantial advancement of industrial democracy has been made. To the excluded worker, management prerogative has merely been replaced by union prerogative. The union has a legislative power over the worker's economic existence and yet the worker has no voice in making legislative decisions. To deny the worker the right to join the union that represents him is to deprive him of his economic ballot. In view of the power and functions of the representative, it would be expected that the law would take note of the peculiar nature of unions and give intelligent consideration to the question of membership in a labor union.

\section{Admission Policies and tHe LAW}

The law regarding the membership policies of labor unions has been derived from the larger body of law dealing with the internal affairs of unincorporated, voluntary associations. When the first cases arose embodying internal disputes in unions, the courts could see no difference between the voluntary association that was a union and other voluntary associations. Perceiving, then, an existing body of law from which they could extract general principles, the courts applied, almost automatically, the same rules concerning membership, to labor unions. ${ }^{23}$ An examination of these rules shows that their continued application to labor unions may not be sound judicial policy.

The Law of Voluntary Associations-The traditional attitude of the courts toward the internal affairs of voluntary associations has been one of judicial "laissez-faire". Only in what they considered an extreme case, and generally only after all appeal within the association had been exhausted, would the courts act to resolve internal disputes. Three arguments were advanced in support of this position.

1. Authority-The legal mind of the nineteenth century experienced difficulty in placing the social club, the discussion group, the

23. Rigby v. Connol, 14 Ch. D. 482 (1880); Mayer v. Journeymen StoneCutters' Association, 47 N.J. Eq. 519, 20 At1. 492 (1890); Simons v. Berry, 210 App. Div. 90, 205 N.Y. Supp. 442 (1924); Greenwood v. Building Trades Council of Sacramento, 71 Cal. App. 159, 233 Pac. 823 (1925). 
political society in its proper legal niche. ${ }^{24}$ The status of the unincorporated association in a world of nice fictions was obscure. But one thing was clear, it was not an entity, there being only people who had some indefinable relation to one another, and therefore was almost beyond the law, unless property or contract rights happened to be involved. Thus, the courts have often phrased their refusal to act in terms of jurisdiction, or have simply said they lacked the authority to interfere with the internal affairs of associations. ${ }^{25}$

2. Administrative Inconvenience-Another factor which makes the courts reluctant to review decisions or policies of associations is the impracticability of policing the inner conduct of the many different types of clubs and societies. Here, the courts are probably worried about two separate problems. They fear placing themselves in a position where they might become the final arbiter of all intra-club disputes; ${ }^{26}$ better to leave all such disputes alone than to risk involvement in such inflammable subjects as church or trade union policies. Secondly, judges doubt their ability to render satisfactory decisions when in the unfamiliar territory of association rules and customs, especially where the dogma and doctrine of churches or secret societies are involved. ${ }^{27}$

3. Freedom of Activity-The third and primary argument is that personal relationships such as companionship and "mutual enjoyment of association" cannot and should not be compelled by the law. It is better for our society to let groups, like individuals, have as much freedom as possible in the conduct of their private affairs. A person cannot be compelled to enjoy the company of another; neither is it consistent with our traditional concepts of privacy and personal liberty to attempt to force companionship..$^{28}$

24. See Laski, The Personality of Associations, 29 HARv. L. REv. 404, 407, 416 (1916).

25. Forbes v. Eden, L.R. 1 H.L. 568 (1867) ; Kearns v. Howley, 188 Pa. 116, 41 Atl. 273 (1898); White v. Brownell, 2 Daly 329 (N.Y. 1868); American LiveStock Commission Co. v. Chicago Live-Stock Exchange, 143 I11. 210, 32 N.E. 274 (1892).

26 In Dawkins v. Antrobus, 17 Ch. D. 615, 628 (1881), James, L.J. indicated this fear when he said: "We have no right to sit as a Court of Appeals upon the decisions of the members of a club duly assembled." See Kearns v. Howley, 188 Pa. 116, 122, 41 Atl. 273, 275 (1898).

27. In 1867, an English court expressed the latter point in these words:

"None but the members of the club can know the little details which are essential to the social well-being of such a society of gentlemen, and it must be a very strong case to induce this court to interfere." Hopkinson v. Marquis of Exeter, L.R. 5 Eq. 62, 67 (1867).

28. This line of thought was expressed in McKane v. Adams, 123 N.Y. 609, 612,25 N.E. 1057 (1890) a case involving membership in a political club: "If they . - will not associate with him, upon what reasoning or principle should they be compelied . . .?" 
Hence from the days when the King's Bench refused to force the Bishop of London to "approve" a clerk, ${ }^{29}$ up to the present time, courts have been repelled by the idea of forcing a society to admit a person who was thought to be undesirable. Almost without exception, ${ }^{30}$ no voluntary association has been forced to admit a member against its will; as oft repeated, "membership is a privilege which may be conferred or withheld at its pleasure." 31

\section{Analysis of the Law of Associations as Applied TO LABOR UNIONS}

This, then, was the law which the judges looked to when first confronted with the question of admission to a trade union. Accordingly, the courts of at least three states have held that there is no right to join a union, and many others have stated, by way of dictum, that membership in a labor union is a privilege, completely within the control of the union. ${ }^{32}$ But is the old law of associations applicable to trade unions?

1. Authority-Reflecting the lack of a legal mold for the informal association, the cases often state that only the union, not the court, has authority to confer membership. ${ }^{33}$ How much this is a denial of power or how much it is merely a statement of result is difficult to determine, for very seldom do the courts go further than drawing the analogy to the law of such associations as fraternities and churches. What is probably meant is that denial of membership is not actionable, but rarely are any reasons given. Such judicial reticence may be attributed in part to the dated belief that an association is not a "thing" in the eyes of the law and thus not subject to control.

The difference between social clubs and labor unions, which are in size, power, and structural organization more like corporations,

29. The King v. The Archbishop of Canterbury and The Bishop of London, 15 East 117, 104 ENG. Rep. 789 (1812).

30. See, Creyhon v. Board of Education, 99 Kan. 824, 163 Pac. 145 (1917), People v. Medical Society, 32 N.Y. 185 (1865).

31. White v. Brownell, 2 Daly 329, 358 (N.Y. 1868); Taylor v. Edson, 4 Cush. 522, 526 (Mass. 1849); Richardson v. The Union Congregational Society of Francestown, 58 N.H. 187, 189 (1877).

32. The right to join a union has been denied, although plaintiff was thereby unable to practice his trade in his community, Mayer v. Journeymen Stone Cutters' Assn., 47 N.J. Eq. 519, 20 Atl. 492 (1890) ; where under closed shop agreement plaintiff could not work unless admitted to the union, Walter v. McCarvel, 309 Mass. 260, 34 N.E.2d 677 (1941); although plaintiff withdrew from local on a promise to readmit, Maguire v. Buckley, 301 Mass. 355, 17 N.E.2d 170 (1938); although plaintiffs had been allowed to work under permit cards, Murphy v. Higgins, 12 N.Y.S.2d 913 (Sup. Ct. 1939); and despite the fact that the union was plaintiffs' bargaining representative, Kelly v. Simons, 87 N.Y.S.2d 767 (Sup. Ct. 1949).

33. See Simons v. Berry, 210 App. Div. 90, 205 N.Y. Supp. 442 (1942), Acierno v. North Shore Bus Co., 173 Misc. 79, 17 N.Y.S.2d 170 (1939). 
should dispel this archaic notion. ${ }^{34}$ In James v. Marinship Corp. it was said that a union "may no longer claim the same freedom from legal restraint enjoyed by golf clubs or fraternal associations". ${ }^{35}$ The fact that a union may be a form of voluntary association has not prevented relief against it in cases of wrongful expulsion of a member. $^{36}$ Thus, a court cannot now very well blind itself to reality and refuse to deal with the United Automobile Workers while recognizing a small, incorporated sewing club as an entity. The development of the law, as well as the enactment of statutes such as the Wagner and Norris-LaGuardia Acts, ${ }^{37}$ have generally emasculated the argument that labor unions are untouchable because they are not jural entities.

As injunction is the most appropriate remedy, ${ }^{38}$ a related obstacle, the traditional doctrine that equity protects only property rights, must be bridged. ${ }^{39}$ Judges have apparently found difficulty in thinking of an interest in membership as a right of property. By calling membership a privilege, they are, of course, merely stating the result. But the necessity of a property right for equitable jurisdiction has not deterred the court of chancery when its conscience was offended. Equity has done a great deal for the protection of what could be termed personal rights, usually insisting, however, that property rights are involved. ${ }^{40}$ This doctrine has become diluted by time and is no longer

34. See the extensive discussion of the nature and distinctive quality of labor unions in United Mine Workers of America v. Coronado Coal Co., 259 U.S. 344 (1922), where the Supreme Court held the UMW to be suable as an entity for torts committed by it in a strike.

35. 25 Cal. $2 \mathrm{~d} 721,731,155$ P.2d 329, 335 (1944).

36. Otto v. Journeyemen Tailors' $\mathrm{P}$. and B. Union, $75 \mathrm{Cal} .308,17 \mathrm{Pac} .217$ (1888); Smetherham v. Laundry Workers Union, 44 Cal.App.2d. 131, 111 P.2d 948 (1941) ; Polin v. Kaplan, 257 N.Y. 277, 177 N.E. 833 (1931) ; Simpson v. Brotherhood of Locomotive Engineers, 83 W.Va. 355, 98 S.E. 580 (1919), cert. denied, 250 U.S. 644 (1919); Spayd v. Ringing Rock Lodge, 270 Pa. 67, 113 Atl. 70 (1921).

37. For an exhaustive compilation of federal and state statutes dealing with labor unions and recognizing them as distinct entities at that comparatively early date, see United Mine Workers of America v. Coronado Coal Co., 259 U.S. 344, 386-389 (1922); See also Wilson \& Co. v. United Packinghouse Workers of America, 83 F. Supp. 162 (D.C. N.Y. 1949).

38. Many of the deficiencies of an action for damages in exclusion cases are pointed out in Chafee, Internal Affairs of Associations Not for Profit, 43 HARv. L. REV. 993, 1010-12 (1930).

39. For an analysis and criticism of this doctrine, see Pound, Equitable Relief Against Defamation and Injuries to Personality, 29 HARv. L. Rev. 640 (1916). See Heasley v. Operators, P. \& C. F. Int. Assn., 324 Pa. 257, 188 Ati. 206 (1936).

40. Such persistence has resulted in the discovery of a "property right" in very unlikely places, such as in the right to prevent the unwarranted use of a man's name on a birth certificate, Vanderbilt v. Mitchell, 72 N.J. Eq. 910, 67 Atl. 97 (1907), and in the right to prevent the publication of indiscreet letters, Gee v. Pritchard, 2 Swans. 402, 36 Eng. Rep. 270 (1818). See Note, 37 L.R.A. 783 (1897).

In cases concerning associations or unions, a property right has been found in the goodwill of the local union, Barbrick v. Huddell, 245 Mass. 428,139 N.E. 629 (1923) ; in seniority status, Gregg v. Starks, 188 Ky. 834, 224 S.W. 459 (1920); in the remote right to the club's assets on dissolution, Loubat v. LeRoy, 40 Hun 546 (N.Y. 1886); and in insurance benefits, Gardner v. Newbert, 74 Ind. App. 183; 128 N.E. 704 (1920). 
the bar it once was. Both the requirement of a property right and the theory that the constitution and by-laws constitute a contract between the members, ${ }^{41}$ have been criticized as artificial and inadequate bases for relief. ${ }^{42}$ Whatever the label, the magnitude of the interest of the excluded employee in participating in the bargaining process should easily qualify as a basis for equitable relief.

2. Administrative Inconvenience-Another objection is that the courts do not wish to serve as appellate tribunals for the myriad organizations which exist in the present day world. That judicial review of every action of all types of clubs would be undesirable, as well as impracticable, cannot be questioned. But the recognition and enforcement of a right to join a union need not entail interference with affairs of all other organizations. If it is realized that unions differ greatly from most other types of voluntary associations, and if it is recognized that the real interest protected is the right to have a voice in one's own economic affairs, the courts will not be flooded with demands to be admitted to the Union League, Sigma Chi, or the Twelfth Street Marching Society. Indeed, at the present time, courts do interfere in other situations with the inner conduct of associations and unions to such an extent that the objection of unwarranted overseeing, while valid in theory, should present no legal obstacle. ${ }^{43}$

Nor is it reasonable to assume that the courts are so incapable of understanding the functions and doctrines of labor unions that their decisions would be unrelated to industrial and trade union facts of life. Unions are not secret societies or religious bodies where esoteric dogma or metaphysics might be involved, nor are they social clubs where personalities or individual idiosyncrasies might play a large part. The functions, objectives, and policies of unions are well-known; union rights and duties are defined by labor relation laws and by collective bargaining agreements. Whether or not the policy for admitting an excluded applicant overbalances the policy against interfering with union affairs is a question that can be decided by the courts. Such a test would be no more difficult to administer than that of due process, natural justice, or good faith used in connection with expulsions from

41. Krause v. Sander, 66 Misc. 601, 122 N.Y. Supp. 54 (Sup. Ct. 1910).

42. Chafee, Internal Affairs of Associations Not for Profit, 43 Harv. L. Rev. 993 (1930).

43. When the proper prerequisite of a property or contract right has been found to exist, courts have remedied expulsions, see cases cited in note 36 supra; enjoined the use of union funds for a purpose other than that intended, Howden v. Yorkshire Miners' Assn., [1903] 1 K.B. 308; compelled completion of judicial process within a union, International U. of S. and O. Eng. v. Owens, 119 Ohio St. 94, 162 N.E. 386 (1928); decided disputes between different factions of a church, Monk v. Little, 122 Ark. 7, 182 S.W. 511 (1916); and have otherwise interfered with association activity. 
associations. ${ }^{44}$ In most cases, the judiciary should certainly be capable of reaching satisfactory and just results in cases involving admission to a union.

3. Freedom of Activity-The most important objection to compeling a voluntary association, or a union, to admit an applicant to membership has been the natural reluctance to enforce personal relationships. ${ }^{45}$ This is both an expression of the spirit of individualism, that men and groups of men should be free to run their own affairs, and a recognition of the futility of ordering a person to enjoy the company of another by court decree. ${ }^{48}$

The latter position, while sound in reason, misses the mark, for it is unrealistic in the light of present day unionism. Even at the time when the law of voluntary associations was first applied to trade unions, an appreciation of the unique features of trade unions such as the factor of common employment, the distinctive modes of organization, and their economic functions and objectives, coupled with a knowledge of the history of unionism in England and in this country, ${ }^{47}$ might have led the courts to reach a different result. In 1890, when organized labor consisted of about 500,000 members of small craft unions, the view that only interests of personality were involved might be excused. But in 1950, with almost 16 million members, many of whom are in large industrial unions where single locals may number thousands of members, and with collective bargaining in operation, it would seem strange to hear a court announce that it will not, under any circumstances, consider enforcing a right to membership because a person cannot be compelled to enjoy the social companionship of another. Yet that is what a court does say, in effect, when it adopts the law of voluntary associations, either expressly or by stating that "membership is a privilege which may be conferred or withheld at its pleasure". 48

The recognition that unions are not sufficiently personal in nature to warrant refusal to admit qualified workers finds analogy in the field of employment. Despite a general doctrine that contracts for personal

44. See Dawkins v. Antrobus, 17 Ch. D. 615 (1881).

45. In Rigby v. Connol, 14 Ch. D. 482, 487 (1880), Jessel, M. R. said “. . the Courts, as such, have never dreamt of enforcing agreements strictly personal in nature..."

46. The later point of view was expressed in Frank v. National Alliance of Bill Posters, 89 N.J.L. 380, 381, 99 At1. 134 (1916): "[It is] impracticable for the courts to undertake to compel men to receive into their social relationships one who [is] personally disagreeable to them ... [Courts] cannot by a mandatory writ intrude one man's companionship upon another."

47. See Webb, History of Trade Unionism, (1911) ; Foner, History of the Labor Movement in the UnIted States, (1947).

48. For recent cases, see Colson v. Gelber, 192 N.Y. Misc. 520 (Sup. Ct. 1948);

Shein v. Rose, 12 N.Y.S.2d 87 (Sup. Ct. 1939). 
services will not be specifically enforced by an affirmative decree, ${ }^{49}$ the legislatures and the courts have ordered employers to reinstate or to hire particular workers. ${ }^{50}$ This action indicates an awareness that under modern industrial conditions the relationship of employer-employee is not usually a personal relationship. The passage of time has brought changes in the organization of industry and changes in willingness to protect individual rights that should be applied to the admission policies of unions.

Even assuming that some personal interests are involved, the outright refusal to order admission of an applicant does not have a sound basis in law. It is inconsistent with the willingness of the courts to remedy wrongful expulsions from associations or unions, which is sometimes called an exception to the general policy of noninterference. When the expulsion was against the rules of the association, or violated the requirements of due process or "natural justice", or was not in good faith, the courts have interfered and, in addition to awarding damages, have ordered reinstatement of the expelled member. ${ }^{51}$ This action is taken, of course, on the theory that some property or contract right is involved. Nevertheless, as has been shown, the property or contract right is often merely a technical one and the real interest protected is the injury to personality. ${ }^{52}$ When an expelled member is reinstated, the courts run counter to their announced policy of non-interference and of not forcing human companionship. The expelled member must be every bit as undesirable to the association as the applicant who has been refused admission. The answer to this apparent dilemma lies in the realization that in certain situations the injury to the interest of the person is sufficient to warrant interference with internal affairs of the association.

Thus, of the underlying reasons, as taken from the law of voluntary associations, for refusal to compel admission to membership, only

49. Shubert v. Woodward, 167 Fed. 47 (8th Cir. 1909) ; Roguemore \& Hall v. Mitchell Bros., 16 Ala. 475, 52 So. 423 (1910); Sheehan v. Vedder, 108 Cal.App. 419, 292 Pac. 175 (1930); Breeden v. Hopkins, 210 App.Div. 412, 206 N.Y. Supp. 282 (Sup. Ct. 1924). For negative enforcement, see Lumley v. Wagner, 1 De G.M. \& G. 604 (Ch.App. 1852).

50. National Labor Relations Act, 61 Srat. 136 (1947), 29 U.S.C. \&141 et. seq. (Supp. 1949) ; NLRB v. Jones and Laughlin Steel Corp., 301 U.S. 1 (1937) ; Phelps Dodge Corp. v. NLRB, 313 U.S. 177 (1941) ; Texas and N.O.R.C. Co. v. Brotherhood of Railway and S.S. Clerks, 281 U.S. 548 (1930). See also the provisions of the New York F.E.P.C. statute, N.Y. Laws c. 118 (1945).

51. Spayd v. Ringing Rock Lodge, $270 \mathrm{~Pa} .67,113$ Atl. 70 (1921); Otto v. Journeymen T.P. \& B. Union, 75 Cal. 308, 17 Pac. 217 (1888); Reilly v. Hogan, 32 N.Y.S.2d 864, aff'd, 264 App. Div. 855, 36 N.Y.S.2d 423, appcal denied, 265 App.Div. 805, 37 N.Y.S.2d 426 (1942); Gleeson v. Conrad, 81 N.Y.S.2d 368 (Sup. Ct. 1948), $a f^{3} d, 93$ N.Y.S.2d 667 (1949). For a recent case see Cason v. Glass Bottle Blowers Ass'n, 220 P.2d 34 (Cal. 1950) 99 U. of PA. L. Rev. 698 (1951).

52. Chafee, supra note 42. 
the policy favoring individual freedom of activity remains as an important consideration. But this concept of individualism has come to include action of the government, by judicial and legislative means, to protect the freedom of individuals in less favored positions from limitations imposed by more powerful interests. Modern trends have been toward curtailment of the power of individuals to control what was formerly considered their private affairs, as evidenced by exercise of the state police power and by such measures as minimum wage, equal pay, child labor, and social security legislation. Further, the fact that reinstatement of expelled members has been ordered shows that the union's interest in freedom of activity in the membership field is not inviolate.

Another factor, not derived from association law, is the policy, existing at least until the Taft-Hartley Act, supporting the formation and growth of labor unions. Should the recognition of a right to membership hamper the organization or effectiveness of unions, ${ }^{53}$ the permissible extent of hindrance of the policy favoring strong unions must be determined. Also, since voluntary collective bargaining is the basis of our labor policy, the possibility of interference with this principle should be considered.

Hence, the problem confronting a court would be that of weighing the respective interests-the needs of the excluded worker and the interest of the union in freedom of activity and in performing its role efficiently. As outlined before, the interests of the worker are strong: democratic industrial government, and the sense of human dignity deriving from participation in that government. The union has such concerns as maintenance of a strong union with a loyal membership capable of effective action and the pursuit of legitimate goals unhampered by undue use of courts or other agencies. On this point, it seems unlikely that ordering a union to admit, for example, all Negroes in the bargaining unit would constitute an unwarranted interference with the union's interest in freedom of activity generally or its interest in effective and voluntary collective bargaining in particular.

The essential step is to place the matter on the agenda, so that when and if interests conflict they can be resolved on an intelligent basis. A "laissez faire" attitude toward the internal affairs of unions cannot be severely criticized, but when courts refuse to help individuals

53. For example, a union might be more successful by living with local prejudice than by crusading against it. On the other hand, inclusion of all groups may very well increase union effectiveness. On the question of method, it has been suggested that allowing employers to use discrimination in membership as a defense might delay NLRB action. Summers, The Right to Join a Union, 47 CoL. L. REv. 33, 6466 (1947). 
who need judicial aid they are abdicating their responsibility to society. To do so because of antiquated rules aggravates the offense.

\section{Bases for Judicial Protection of the Right to Membership}

Protection of the interests of the excluded worker can be provided by judicial recognition of a right to join a union. In view of the persistent statements that membership in a union is a privilege, the possibility of such a forward step might seem remote. But even in the states where it has been held that there is no right to join a union, the courts have expressed dissatisfaction with the rule that denies protection to the worker.

In a New Jersey case involving the right to work and the right to membership, which was dismissed on the promise of the union to afford opportunity to join, the court said that a union should admit all qualified applicants on reasonable terms, adding:

"Autocracy is no less inimical to our American ideal if practiced by many rather than one. . . . If the characterization of a union as a voluntary association becomes in time a mere anachronism, the mere word 'voluntary' will not preserve the present state of the law." 54

In Miller $v . R u e h l,{ }^{55}$ where a New York court refused to compel the union to accept an applicant on the ground that the legislature should take the initiative, it was stated that:

". . . to the ordinary man it may appear somewhat odd that a person who apparently is qualified under the rules of the union to become a member is rejected by the union solely on the ground that the union does not care to have him as a member."

Analysis of the law of associations has revealed its inadequacies as applied to unions. Modifying that law, courts can recognize a right to membership as a matter of "common law". Further, enforcement of such right may be dictated by sound judicial interpretation of statutes and of the Constitution.

\section{Common Law Right to Join a Union}

The most inclusive solution of the admission problem is by purely judicial action, the recognition of a right to join a union as a matter of general legal principles. In view of past results, it might seem unduly hopeful to expect the courts to recognize and enforce such a right.

54. Carroll v. Local No. 269, 133 N.J. Eq. 144, 147, 31 A.2d 223, 225 (1943).

55. 166 Misc. 479, 2 N.Y.S.2d 394 (1938). 
But, as has been pointed out, the reasons for the old common law rule do not apply to labor unions as they exist today. In only three states are the courts hampered by a holding of no right to join, ${ }^{56}$ and in these three the problem has been partially solved by legislation. The decisions and dicta denying the existence of a right to membership should be cast aside as the law progresses. As stated in Carroll $v$. Local No. 269: ${ }^{57}$

"It is the peculiar genius and strength of the common law that no decision is stare decises when it has lost its usefulness in our social evolution; it is distinguished, and if times have sufficiently changed, overruled. Judicial opinions do not always preserve the social statics of another generation."

The recognition and enforcement of a right to membership may well result from a declaration by the court that unreasonable exclusion is against public policy. ${ }^{58}$ The courts as well as the legislature can express the public policy of a state or nation; as stated in Williams $v$. International Brotherhood of Boilermakers: ${ }^{50}$

"Although the relief granted in the Corsi case was derived from legislative authority [FEPC legislation in New York] nevertheless, it is established that, where persons are subjected to certain conduct by others which is deemed unfair and contrary to public policy, the courts have full power to afford the necessary protection in the absence of statute."

Although such a step forward is an important one, it neither constitutes any great change nor rests on novel grounds. Dean Pound has demonstrated the importance of relation in our law, resulting from an infusion of the feudal law of lord and tenant. ${ }^{60}$ The law defines rights and duties concomitant with such relations as principal and agent, master and servant, man and wife, trustee and beneficiaries, all of which duties are above and beyond the agreement, if any, between the parties. In cases of expulsion from associations, Professor Chafee has shown that the true subject matter protected is the relation of the member to the association. ${ }^{61}$ Applied to unions, this relation is the important and binding one of bargaining representative and employee. That the relational concept is a living element in our law is shown by the in-

56. Massachusetts, New York and New Jersey; see cases cited note 13 supra.

57. Carroll v. Local No. 269, 133 N.J. Eq. 144, 147, 31 A.2d 223, 225 (1943).

58. See James v. Marinship Corp., 25 Cal.2d 721, 155 P.2d 329 (1944).

59. $27 \mathrm{Cal} .2 \mathrm{~d} 586,590,165$ P.2d 903, 905 (1946). For deference paid by the Supreme Court in picketing cases to state policy expressed through the judicial organ see Hughes v. Superior Court of California 339 U.S. 460, 466-9 (1950), and International Brotherhood of Teamsters v. Hanke, 339 U.S. 470, 479 (1950).

60. Pound, Spirit of the Common Law (1921).

61. Chafee, supra note 42. 
cidents the law has placed on the relations of insurer and insured and public utility and patron. Legislation such as Workmen's Compensation and Social Security, and labor's demands for insurance and pensions are extensions of the incidents growing out of the relation of employer and employee. The union as a distinct body has been created by the employees; it has undertaken to act for the employees. Because of its assumption of the position of bargaining representative and acceptance of the privileges of such a position, the union should be required to accept a corresponding duty to admit the employees to membership. The recognition of the relation of bargaining representative and employee provides a conceptual base for the right to membership. The powers and functions of the bargaining representative make the duty to admit a necessary incident of the relation.

The arising of the relation and the attendant right to membership would not mean, however, that the right to admission would be absolute and automatically enforced by the courts. The duty to admit depends on the relative interests of the employee and the union. A court should not, for example, order the union to admit someone whose only interest is to weaken or disrupt the union. ${ }^{62}$ Categorization of justifiable grounds for exclusion may be left to the courts, but in no case should exclusion solely because of race or religion be justified.

The advantage of recognizing a common law right to join a union is the resultant flexibility; no particular statute need be relied on, and state and federal boundaries should present less of a problem.

\section{Statutory Right to Join a Union}

Statutory interpretation, based on similar reasoning, provides another method whereby a right to membership may be enforced. True, no express provision to this effect will be found in the Wagner Act. Nor will any such provision be found in the Taft-Hartley Act, although it does provide protection for excluded workers under a union shop. ${ }^{63}$ However, explicit wording is not necessary; a sound statutory interpretation is that which effectuates the purposes of the statute.

62. In Miller v. Ruehl, 166 Misc. 479, 2 N.Y.S.2d 394 (Sup. Ct. 1938), one of the reasons the court would not recognize a right to membership was that persons inimical to the union might then force themselves into membership. If courts are aware of the true interests involved, such a result need not be feared.

63. Section $8 \mathrm{a}(3)$ of National Labor Relations Act, as amended, provides that an employer cannot justify discrimination against an employee for non-membership in a union under a union shop contract if the employer has reasonable grounds to believe that membership in the union was not open to such employee or that membership was denied or terminated for any reason other than non-payment of regular dues or initiation fees. 61 STAT. 136 (1947), 29 U.S.C. \$\$ 141, 158a(3) (Supp. 1949). This section and companion section $8 \mathrm{~b}(2)$ are not directed toward the instant problem of membership. See Conf. Rer. No. 510, 80th Cong., 1st Sess. 41-43 (1947). For 
Here, a primary purpose was to give employees a representative to bargain in their behalf. ${ }^{84}$ In view of the power given to that representative, particularly that of representing all of the employees in the unit, it should be bound by a duty to admit. By empowering the union to legislate, in effect, for all the employees, the framers of the Act must have intended that every employee should be able to participate in such legislation.

This reasoning is similar to that of the Supreme Court in Steele $v$. Louisville and Nashville Railroad Co. where, although it did not pass upon the question of a right to membership, it read into the Railway Labor Act the duty to represent fairly all the employees in the unit. ${ }^{85}$ Though no duty to represent fairly was spelled out in that statute, such an obligation was deemed a necessary adjunct to the powers conferred in the Act.

Section 9 (a) of the NLRA provides that the union designated by the majority of the employees in the unit shall be the exclusive representative for all the employees in the unit. Drawing an analogy to democracy in the political field, the sponsors of the act adopted, in this section, the principle of majority decision." The "majority rule through representation principle" extends further than the mere selection of the union, for the chosen union itself becomes a legislative forum for the employees, a continuing government. Unless all can participate in the control of that government, it is not a "representative", voicing the views of those it represents. Without membership, the voice of all the people is not heard. In order for majority decision to be operative all employees in the unit must have a right to be members of the union.

Although no case holds that a duty to admit all employees arises under these statutes, and although recent NLRB decisions seem to

a better resolution of the problem of union security and the right to work, see Mass. Gen. Laws (1947), c. 150A, $\$ \S 4,6 \mathrm{~A}$, which provides for certification of the reasons for exclusion by the union to the employer and for review of such exclusion by the Labor Relations Commission.

64. Congress intended to protect "the exercise by workers of full freedom of association, self organization, and designation of representatives of their own choosing, for the purpose of negotiating the terms and conditions of their employment or other mutual protection." 61 STAт. 136 (1947), 29 U.S.C. \$151 (Supp. 1949). Unions limited to "white christian males" cannot be true collective bargaining representatives of other groups.

65. The Supreme Court found this duty to be an inherent feature of the Act and did not delve into legislative history. On the membership issue, an excursion into legislative history would probably provide no answer. H.R. REP. No. 1147, 74th Cong., 1st Sess. (1935) ; Conf. REP. No. 1371, 74th Cong., 1st Sess. (1935), and CoNF. Rep. No. 510, 80th Cong., 1st Sess. (1947), do not discuss the problem. Sen. REP. No. 105, 80 Cong., 1st Sess. (1947), however, contains language to the effect that at least $\$ \S 8 \mathrm{a}(3)$ and $8 \mathrm{~b}(2)$ do not limit the union's power to select members.

66. See Legislative History of the National Labor Relations Act 3069-72 (1935) ; Weyand, Majority Rule in Collective Bargainizg, 45 CoL. L. REv. 556, $561-63(1945)$. 
deny its existence, some courts have indicated that a duty to admit is a necessary corollary to the right to bargain for all. In a case setting aside the National Mediation Board's ruling that the employees excluded by the majority representative could not set up their own craft unit, Chief Justice Groner termed such exclusion "a tyranny in many respects analogous to 'taxation without representation' " and said:

". . . the effect of the action of the Board is to force this particular group of employees to accept representation by an organization in which it has no right to membership, nor a right to speak or be heard in its own behalf. . . . [This is] so inadmissible, so palpably unjust and so opposed to the primary principles of the Act [RLA] to make the Board's decision upholding it wholly untenable and arbitrary." 67

Another approach may be that the duty to admit need not be considered a separate obligation imposed by the statute but is necessarily included in the duty to represent fairly. The duty is not that of "ruling" fairly but of "representing" fairly, which implies participation by members of the unit. In view of the power of the union and the legislative nature of its functions, the conclusion that representation is not truly "fair" unless it includes a reasonable opportunity to join the union seems inescapable.

“. . a reasonable interpretation of the statute [the $\mathrm{Na}$ tional Labor Relations Act], together with its underlying policy, would seem to require that unions chosen to represent the employees must be open to all who wish to join. . . . It is difficult to see how a union can fairly represent all the employees of a bargaining unit unless it is willing to admit all to membership, giving them the opportunity to vote for union leaders and to participate in determining union policies." 68

The recognition of a statutory duty to admit all employees in the bargaining unit would clearly be in furtherance of the policy of the National Labor Relations Act favoring a representative system of industrial relations. ${ }^{69}$ Though it seems to be the Board's positionand it is supported by the Supreme Court dictum in the Steele case- ${ }^{70}$

67. Brotherhood of Railway and S.S. Clerks, etc. v. United Transport Service Employees of America, 137 F.2d 817, 822 (D.C. Cir.) (concurring opinion), reversed on the ground that NMB certifications are not subject to review, 320 U.S. 715 (1943).

68. James v. Marinship, 25 Ca1.2d 721, 735, 155 P.2d 329, 337 (1944).

69. See footnote 42 supra.

70. "While the statute does not deny to such a bargaining labor organization the right to determine eligibility to its membership. . "323 U.S. 192, 204 (1944). Against this dictum it might be argued, as FEPC adherents argue, that the union could still determine eligibility to membership but in doing so must not discriminate for reasons such as race, creed, or national origin. For the NLRB's position see text infra. 
that the statute imposes no such duty, the issue has not yet been put to rest. Nor will the democratic objectives of the statute be realized until the courts do find in its language a mandate to admit all applicants on reasonable terms.

\section{Constitutional Right to Join a Union}

It has been suggested that since unions have been given protection and powers under the Railway Labor Act, the National Labor Relations Act, and state labor relations acts, discriminatory exclusion would be a violation of the Fifth or Fourteenth Amendments. The theory supporting a constitutional right to membership is that the exclusionary acts of a union operating under powers given by a state are "state action" within the Fourteenth Amendment, ${ }^{71}$ or that the union is functioning as an arm of the federal government under the National Labor Relations Act or Railway Labor Act and its action is therefore limited by the Fifth Amendment. ${ }^{72}$ In Betts $v$. Easley, ${ }^{73}$ it was held that the bargaining representative, in exercising statutory bargaining power, was functioning as an agency of the United States Government and was thus prohibited by the Fifth Amendment from denying a minority the right to participate. The court there enjoined a union which discriminated against Negroes, by placing them in an "auxiliary" local under the supervision of white locals, from operating as bargaining representative of the class as long as it denied Negroes the right to participate. The court said:

"In the light of the history and purposes of the Act . . . [the] view that the acts complained of are solely those of a 'private association of individuals' is wholly untenable. The acts complained of are those of an organization acting as an agency created and functioning under provisions of Federal law." 74

and found that:

"the denial to a workman, because of race, of an equal voice in determining issues . . . is an infringement of liberty if indeed it may not also be said to be a deprival of property rights." 75

71. “. . . nor shall any. State deprive any person of life, liberty, or property, without due process of law; nor deny to any person within its jurisdiction the equal protection of the laws." U.S. Const. AMEND. XIV, §1.

72. ". . . nor [shall any person] be deprived of life, liberty, or property, without due process of law . . " U.S. ConST. AMEND. V.

73. 161 Kan. 459, 169 P.2d 831 (1946). The court distinguished National Fed. of R. Workers v. NMB, 110 F.2d 529 (D.C. Cir. 1940) and pointed out that that case relied on an overruled "white primary" case, (Grovey v. Townsand). The contrary has been held for federal jurisdiction purposes: Pullman Standard Car Mfg. Co. v. USWA, 152 F.2d 493 (7th Cir. 1945) ; Courant v. International Photographers of Mot. Pic. Ind., Local No. 659, 176 F.2d 1000 (9th Cir. 1949).

74. Betts v. Easley, supra at 467,169 P.2d at 838 . 
A strong argument can be made for the position that discrimination by the union that is bargaining representative is an infringement of constitutional rights. The Railway Labor Act, the National Labor Relations Act and similar state statutes give unions broad protection in the right to organize. At least one purpose of such laws is "to eliminate the causes of certain substantial obstructions to the free flow of commerce". ${ }^{76}$ In the Clayton Act and in the Norris-LaGuardia Act, unions receive protection against injunctions. Elections of the bargaining representative are held at public expense by a governmental agency, which also certifies the union as the bargaining representative. The government compels the employer to bargain with the selected union. Under these circumstances, it is not unreasonable to say that union action is government action for the purpose of adherence to constitutional requirements.

The argument can be put in its strongest form, however, when it is emphasized that the union selected by the majority has been vested with the statutory power to represent all the employees in the unit. This means that the union is the exclusive agency for negotiations with the employer and that the collective bargaining agreement is binding upon all the employees. Without the statute, the union has no such right. ${ }^{77}$ In effect, Congress has delegated a legislative power to the bargaining representative; the union has been given the authority to act for all, to make the rules that govern the economic life of the workers. In an important case upholding the non-communist oath of the TaftHartley Act, the Supreme Court referred to the effect of this role of the government:

"But that power [of the union] is never without responsibility, and when authority derives in part from Government's thumb on the scales the exercise of that power by private persons becomes closely akin, in some respects, to its exercise by Government itself."

75. Id. at 474,169 P.2d at 842 . Under a recent California decision, Sei Fujii v. California, 97 Adv.Cal.App. 154, 217 P.2d 595 (1950), union discrimination might be held to violate the United Nations Charter. The reasoning of this case has been criticized by Professor Hudson of the Harvard Law School, N.Y. Times, May 14, 1950, p. 7, col. 1. In this connection, see also Groner and Helfeld, Race Discrimination in Housing, 57 YALE L.J. 426, 455-6 and cases cited.

76. 61 Stat. 136, 29 U.S.C. $\$ 157$ (Supp. 1947).

77. National Maritime Union of America v. Herzog, 78 F. Supp. 146 (D.C.), aff'd, 334 U.S. 854 (1948).

78. American Communications Association, CIO v. Douds, 339 U.S. 382, 401-2, (1949). Later the court said it was not suggesting that unions, by use of the NLRA, become government agencies or may be regulated as such. Then it qualified the qualification: "But it is plain that when Congress clothes the bargaining representative 'with powers comparable to those possessed by a legislative body . . ' the public interest in the good faith exercise of that power is very great." 
The courts have recognized that collective bargaining is a governmental process. In NLRB v. Highland Park Manufacturing Co., ${ }^{79}$ it was said:

"The purpose of a trade agreement is . . . to provide a statement of principles and rules for the orderly government of the employer-employee relationship in the future. The trade agreement thus becomes, as it were, the industrial constitution of the enterprise."

Although it avoided the constitutional issue, the Supreme Court in Steele v. Louisville and Nashville Railroad $\mathrm{Co}^{80}$ said:

"Congress has seen fit to clothe the bargaining representative with powers comparable to those possessed by a legislative body ..."

and again,

". . the representative is clothed with power not unlike that of a legislature which is subject to constitutional limitations on its powers to deny, restrict, destroy or discriminate against the rights of those for whom it legislates. . . ."

The court also indicated that if the statute were not interpreted to include a duty to represent fairly, constitutional questions would arise. Because a finding of federal action would be necessary before a constitutional question could arise, the court was thereby intimating that a union's acts could be considered federal action. ${ }^{81}$

Perhaps the best authority supporting a constitutional right to join a union are the "white primary" cases. In Smith v. Allwright, ${ }^{82}$ the Supreme Court held that a resolution of the state convention of the Democratic Party, a voluntary association, excluding Negroes from participation in primaries by excluding them from membership was state action and thus violated the Fifteenth Amendment. The action of the state in regulating party affairs and elections was little more than the action of the state or federal government on behalf of unions. In Rice v. Elmore, ${ }^{83}$ where South Carolina had divorced the primaries from all state control, the denial of primary ballots to Negroes was held to violate the Fourteenth and Fifteenth Amendments. Significant is the emphasis placed on the nature of the acts done, the court not concentrating solely on the question of who is acting. ${ }^{84}$ These cases show

79. 110 F.2d 632, 638 (4th Cir. 1940).

80. 323 U.S. 192, 198, 202 (1944).

81. See Note, 61 HARV. L. Rev. 344, 346 (1948).

82. 321 U.S. 649 , (1944).

83. 165 F.2d 387 (4th Cir. 1947), cert. denied, 333 U.S. 875 (1948).

84. See Comment, 61 HaRv. L. REv. 1247 (1948). 
that voluntary associations are not immune from constitutional limitations and that constitutional rights are to be guarded vigilantly in elective and representative proceedings.

Another pertinent case is Marsh $v$. Alabama. ${ }^{85}$ It was held that a state could not impose criminal punishment on a member of Jehovah's Witnesses for distributing religious literature on the premises of a company-owned town against the wishes of the town's management. Presumably, the punishment could have been enforced for trespass on an individual's private property. The distinction must rest on the fact that this was a company town, where the corporation had governmental power over the people. In regard to this, the court said that the fact that privately owned property was involved did not "justify the State's permitting a corporation to govern a community of citizens so as to restrict their fundamental liberties . . ." Thus, as in Smith v. Allwright and Rice v. Elmore, the nature and public importance of the acts or functions of the particular agency involved may be determinative of the constitutional issue.

The analogy to unions is clear. In negotiating a collective bargaining contract, and otherwise representing the workers, the recognized union is exercising legislative and governmental power. This power has been derived from the state or federal government, for without the statute the union has no right to be exclusive representative. Affecting millions of people, union action is of high public importance. There are objections to imposing constitutional limitations on unions, as there are always objections to any form of federal regulation. The problem of drawing lines may arise, but how far the line extends beyond the inclusion of union activity need not be considered here. In this constitutional question, the most important factor is that the union has been given by Congress the power to speak for and bind others. Where such power exists and may affect a substantial segment of our population and economy, the evils of racial discrimination cannot be tolerated. In accepting and exercising the protection and powers given to them by the government, unions should be required to observe the attendant constitutional duties.

\section{Protection by Other Agencres}

\section{The National Labor Relations Board}

The Railway Labor Act and the National Labor Relations Act provided for national boards to administer each act. Contending with the most discriminatory unions, the railway unions, the NMB has had

85. 326 U.S. 501 (1946). 
virtually no success in remedying racial discrimination in the railroad industry. ${ }^{86}$ With stronger powers and with a more democratic segment of labor under its wing, it could be expected that the NLRB would have had more success in securing democratic admission practices. And the NLRB has done more, but not much more, ${ }^{87}$ to use its power to protect minority interests. It has declared that race is irrelevant in determining the bargaining unit ${ }^{88}$ it has recognized and enforced a duty of fair representation $;^{82}$ and has protected the right to work..$^{90}$

In Bethlehem-Alameda Shipyard, Inc., ${ }^{91}$ the Board said:

"We entertain grave doubt whether a union which discriminatorily denies membership to employees on the basis of race may nevertheless bargain as the exclusive representative in an appropriate unit composed in part of members of the excluded race."

In Carter Mfg. Co., ${ }^{92}$ where the Board equated fair representation to membership, the Board said:

"In the absence of proof that the Union discriminatorily denies membership to employees in the appropriate unit because of their race, we see no reason to dismiss its petition."

This is the closest the NLRB has come to recognizing a right to membership. Since these cases, the Board has retired to the position that it has no authority to pass on the eligibility for membership. Thus, in many cases it has declined to withdraw or to refuse certification on the ground that the union would not admit all the employees to membership, as long as there was no showing that the union would not accord the employees adequate representation. ${ }^{93}$

The fallacy in this reasoning of the Board is that, in view of the power and functions of the representative, adequate representation cannot be ensured without actual participation by the employees in the unit. "Fair" representation may have only theoretical significance without the right to membership. Even the discrimination revealed by court proceedings, which must be only a fraction of the total, demonstrates

86. For a discussion and criticism of the actions of the NMB, see Aaron and Komaroff, Statutory Regulation of Union Affairs, 44 ILL. L. REv. 425, $428-38$ (1949); see also, Brotherhood of Railway and S.S. Clerks v. United T.S.E.A., 137 F.2d 817 (D.C. Cir. 1943).

87. For a discussion and criticism of the inaction of the NLRB, see Aaron and Komaroff, supra note 86 , at $438-446$.

88. United States Bedding Co., 52 N.L.R.B. 382 (1943).

89. Larus \& Brothers Co., 62 N.L.R.B. 1075 (1945).

90. Wallace Corporation, 50 N.L.R.B. 138 (1943).

91. 53 N.L.R.B. 999,1016 (1943).

92. 59 N.L.R.B. 804,806 (1945).

93. Norfolk Southern Bus Line, 83 N.L.R.B. 15 (1949); Veneer Products, 81 N.L.R.B. 492 (1948); Texas and Pacific Motor Transport Co., 77 N.L.R.B. 15 (1948). 
that the duty of fair representation without the right to membership has not provided sufficient protection. ${ }^{94}$ By such reasoning, and by its failure to recognize the inherent dangers of segregation, ${ }^{95}$ the Board has chosen to adhere to verbal theory rather than realistic solutions.

The Board's position is subject to the criticism that a duty to admit all employees in the unit can be read into the act just as the duty to represent fairly was read into the act. In fact, the right to membership could be recognized by an interpretation of the duty of fair representation to include the duty to admit on reasonable terms. As has been shown, fair representation is no substitute for full participation. The certification of a discriminatory union as bargaining representative puts the Board's stamp of approval on a contradiction in terms. Even if union action is entirely fair, there is no "representation"; no right to be heard has been exercised. The NLRB as the primary agency dealing with labor, should take the initiative in securing fair admission practices. ${ }^{96}$ As it has done in other situations, the Board should construe the Act and its power under the Act in such a manner as to effectuate the policy behind the Act. It is unlikely that such an interpretation would seriously hamper representation proceedings. If it is felt that discriminatory practices by labor organizations are unjust, the Board is perhaps the best agency to decide such questions. The Board has always claimed power to decertify and has exercised it in certain cases. ${ }^{97}$ The least that the NLRB should do is to refuse or to withdraw certification of a union that engages in discriminatory admission practices.

\section{Legislation}

Although existing and proposed legislation dealing with the problem of admissions cannot be considered here in detail, some mention of legislative solutions should be made. ${ }^{98}$

94. See Williams v. International Brotherhood of Boilermakers, 27 Cal.2d 586, 165 P.2d 903 (1946); Graham v. Brotherhood of Locomotive Firemen and Enginemen, 338 U.S. 232 (1949).

95. Atlanta Oak Flooring Co., 62 N.L.R.B. 973 (1945).

96. In Ryan v. Simons, 19 U.S.L. Week, 2183 (N.Y. App. Div., October 18, 1950), non-union employees were refused an injunction against their bargaining representative, a closed union, which negotiated a union shop contract, on the ground that the NLRB has exclusive jurisdiction since the case involves an unfair labor practice where the employer is engaged in interstate commerce. Extension of this doctrine would increase the importance of NLRB policies. On this subject generally, see Cox and Seidman, Federalism and Labor Relations, 64 HARv. L. REv. 211 (1950).

97. Cramp Shipbuilding Corp., 52 N.L.R.B. 309 (1943) ; Shell Petroleum Corp., 52 N.L.R.B. 313 (1943).

98 For an analysis of legislative remedies, see Summers, The Right to Join a Union, supra note 53, at $62-72$ and Newman, The Closed Union and The Right to Work, 43 CoL. L. REv. 42 (1943). 
Currently, at least fifteen states have some legislation dealing with this problem. Eight of these have created Fair Employment Practices Commissions, with power over union membership as well as employment. ${ }^{99}$ Five states have created similar commissions to investigate and study the problem of discrimination, with no sanction provided..$^{100}$ Colorado and Nebraska have policy declarations against discrimination in union membership. ${ }^{101}$ Pennsylvania withdraws the protection of its labor relations act from discriminating unions. ${ }^{102}$

The enforcing agency should depend on the scope and objective of the legislation. If only labor unions are to be required to admit without discrimination, the better method would probably be to give the power to decide these questions to an experienced labor board such as the NLRB or similar state agencies. Such agencies could better resolve membership problems peculiar to unions, such as exclusion because of dual unionism. The agency should have sanctions to enforce cease and desist orders, for mere withdrawal of the act's protection may not affect strong unions. On the other hand, if the program is directed against discrimination because of race, religion and the like, which is the major problem, and an over-all Fair Employment Practices Act is contemplated, perhaps a separate agency competent to deal with all manifestations of such discrimination should be created, with similar powers.

An FEPC-type statute, applying to employers also, would be the most desirable from the point of view of acceptance by labor and fairness to minorities. ${ }^{103}$ The worker should not be deprived of equal employment opportunities while waiting for social prejudice to come

99. Conn. Gen. Stat. $\$ \S 7401-7407$ (1949) ; Mass. Ans. Laws tit. 4, c. 151-B, $\S \S 1-10$ (Supp. 1950) ; N.J. STAT. ANN. tit. 18, c. 25-6 (Supp. 1950) ; N.M. Stat. ANN. $\$ \$ 57-1201-1214$ (Supp. 1949) ; N.Y. LAwS ANN. tit. 18, \$\$ 127-135 (McKinney, Supp. 1950); Ore. Laws c. 221 (1949); R.I. P.L. c. 2181 (1949); Wash. Laws c. 183 (1949). The usual procedure of such commissions is to receive complaints, investigate, hold hearings and issue cease and desist orders, enforceable in court. A number of cities, including Philadelphia, Cleveland, Minneapolis and Chicago also have commissions.

100. Ill. Stat. Ann. c. 127, $\$ 214.1-214.5$ (Supp. 1950) ; Ind. Stat. Ann. tit. 40, $\$ \$ 40-2301-40-2306$ (Supp. 1947); Kansas: House Joint Resolution No. 1 adopted April 5, 1949; Nebraska: Resolution No. 25 of the Legislature, adopted May 3, 1949; Wis. Stat. $\$ \$ 111.31-111.34$ (1947).

101. Colo. Stat. Ann. c. 131 , \&7 (1943); Kan. Gen. Stat. Ann. \$\$ 44-80 (Supp. 1947); NEB. REv. STAT. \$\$48-214-48-216 (1943). Apparently the criminal sanction provided has seen little, if any, use.

102. Unions which exclude because of race, creed, color or political affiliation are omitted from the definition of "labor organization." PA. STAT. ANN. tit. 43, $\$ 211.13$ (f) (Purdon 1946). Many states concern themselves only with membership policy in conjunction with union security contracts. See KILLINGSWORIH, STATE LABOR RELATIONS ACTS 103-110 (1948).

103. See Note, Fair Employment Practices,-A Comparison of State Legislation and Proposed Bills, 24 N.Y.U.L.Q. REv. 398 (1949); Hearings before Committee on Education and Labor on $H$. R. 4453, 81st Cong., 1st Sess. (1948). (passin) 
to an end. Where FEPC has been tried it has worked well and it is perhaps the best legislative solution to the problem of economic discrimination. ${ }^{104}$ However, the difficulties in getting such a measure passed by the United States Congress are well known, ${ }^{105}$ and state FEPC laws must stop at state lines. A bill dealing with labor organizations alone would probably have a better chance of passing, but not much better.

What the standards for admission may be and what discriminatory practices should be outlawed will not be outlined here. One proposal suggests that representatives should not be allowed to:

"refuse membership to, or to expel, or segregate, any person by reason of such person's race, creed, color, sex, national origin, foreign nationality or lack thereof, opinion, or lack of United States citizenship." ${ }^{106}$

The important consideration is that no unreasonable exclusion, depriving a worker of his right to vote in his economic legislature, should be tolerated.

The advantage of judicial action is that the machinery already exists-no legislation need be passed, no additional agency need be created-and that less danger of encroachment on other union activities is present. The advantage of an agency is that it may be more thorough and expert in exclusion cases. If the courts play a positive role by protecting the interests of the excluded worker, discriminating unions may reform their admission policies. ${ }^{107}$ If internal reform does not provide an early solution and if judicial action does not succeed in stamping out membership restrictions, new legislation, creating an action agency, will become necessary as the effective answer to discriminatory admission policies of unions.

104. See, Annual Report of New York State Commrssion Against DisCRIMTNATION (1946, 1948) ; Aaron and Komaroff, supra note 86, at 462-466; Graves, Anti-Discrinination Legislation in the American States, 65 Pub. AfFaIRS Buld. 4042 (1948); Annual Report, N.J. Dept. of Education, Division Against Discrimination (1948-9); Fair Emp. Pract. Comm. City of Philadelphia, Annuat REPORTS, (1949, 1950).

105. For a study of the efforts to have FEPC enacted, see Kesselman, THE Social Policies of FEPC (1948).

106. Proposed by the American Civil Liberties Union, February, 1947.

107. For example, in May 1946, after the Marinship and Williams cases, the Boilermakers ordered their California affiliates to abolish auxiliaries and admit Negroes to full membership. For other recent changes, at least partially caused by court and FEPC policies, see MURRAx, The NEGRo HANDBOoK 162-167 (1949). The hope is that, as in other fields, a few court decisions will cause many reforms so that at least a partial cure can be effected at less cost. The sanction of law, unexercised, can help union leaders initiate reforms and induce union members to support fair admission policies. 


\section{CONCLUSION}

The good that would result from recognition of a right to membership is both tangible and intangible. The tangible element comprises the exercise by the admitted worker of his economic franchise and the measure of self protection derived therefrom. The intangibles are the sense of "belonging" to the important group and the feeling of human dignity resulting from sharing in the guidance of his own destiny.

Neither the principle protecting the right to work without unreasonable interference nor the doctrine of a right to fair representation will supply these needs; only membership will suffice. Membership will make the right to be represented fairly a reality, for it will provide greater protection, in that there is both less desire and less opportunity to hurt members, and, more important, it will give meaning to the word "represented". Without membership there is no representation; with membership, representation exists.

As the law has not set itself against protection of the individual worker, it may, by adopting these or similar principles, progress toward the recognition of a right to full membership in a union. Such judicial recognition is not of course a patent medicine, a cure all. But this action would not only confer important rights immediately but would also tend to eliminate the causes of unfair treatment and unjust exclusion. ${ }^{108}$

Any rational analysis of minority rights and labor unions must take cognizance of the interdependent nature of the problem. The issue of a right to be a full participating member of a union does not lie in a vacuum; nor is union membership an isolated field, disassociated from other human activity. As the problem is primarily one of racial discrimination, no entirely satisfactory solution will be reached in the labor field as long as prejudice operates in such other areas as education, political rights, housing and social activity. It cannot be expected that the Negro will be accepted as a full-time partner in one area while not so accepted in another. Discrimination, unfairness, lack of equal opportunity in all fields will always tend to erect some mental barrier, no matter how slight, that prevents full participation in union affairs.

108. The experience of unions and of Fair Employment Practices Commissions has shown that association dispels the fears and antagonism fostered by unreasoned prejudice. See Sumisary of Minutes, CiO Civil Rights Staff Conference (1950) ; Simon. Canses and Cure of Discrimination, N.Y. Times, May 29, 1949, §6, p. 10; Report BY Governor's Interracial Commission of Minnesota, Negro Worker in Minnesota 40-41 (1945); ANNual Report, New Jersey Departasent of Education, Drvision Against Discrimination 6-9 (1946-7). Requiring the organization to adhere to democratic practices should, in itself, influence the attitudes of its members. 
But just as social prejudice fosters economic discrimination, economic favoritism provides one of the strongest pillars of support for social prejudice. Here is a field where forthright action can lead the way. "White monopoly" of economic opportunity and economic democracy is not easily defended.

If the courts are alert to protect workers' rights, the harmful effects of discrimination can be largely eliminated. In the closed union situation the courts can enjoin the union from interfering with the right to work, whether it is the right to obtain or retain employment. If control of hiring is entirely in union hands, the courts should be able to compel admission as a means of protecting the individual's right to work. Finally, unreasonable and arbitrary exclusion can be remedied by ordering the bargaining representative to admit the worker who wants to participate fully in the bargaining process. By taking affirmative action, courts can make a valuable contribution toward the termination of all forms of discrimination. 